\title{
The lichen Thelidium litorale on shells of intertidal limpets: a case of lichen-mediated cryptic mimicry
}

\author{
C. Espoz ${ }^{1}$, G. Guzmán ${ }^{2}$, J. C. Castilla ${ }^{1}$ \\ ${ }^{1}$ Estación Costera de Investigaciones Marinas, Facultad de Ciencias Biológicas, Pontificia Universidad Católica de Chile, \\ Casilla 114-D, Santiago, Chile \\ ${ }^{2}$ Departamento de Biología, Universidad de Playa Ancha de Ciencias de la Educación, Valparaíso, Chile
}

\begin{abstract}
On the intertidal rocky shores of central Chile, the lichen Thelidium litorale (Ascomycete: Verrucariacea) is commonly found encrusting shells of gastropods such as Scurria araucana, $S$. ceciliana and S. boehmita, and plates of the intertidal barnacles Jehlius cirratus and Chthamalus scabrosus. This study focuses on the relationship between $T$. litorale and shells of the limpet $S$. boehmita. In the field, this host shows the highest percentage of lichen prevalence among several intertidal species. Although $T$. litorale is able to penetrate the limpet shell layers lying above the myostracum $(m)$, the observed penetration levels appear related to the width of the shell layers. Among the 3 species of limpets, $S$. boehmita exhibits the thinnest $m+2$ layer and this could facilitate lichen penetration. As a result of the association, the limpet develops an external shell pattern remarkably resembling the shape of the aperture of the intertidal barnacles $J$. cirratus and $C$. scabrosus. This lichen-mediated mimicry can be explained by lichen-induced erosion, which leads to the disclosure of the internal and otherwise unexposed shell design of $S$. boehmita. The possible role of $T$. litorale as a biological modifier of external limpet shell pattern is discussed.
\end{abstract}

KEY WORDS: Central Chile $\cdot$ Intertidal lichen - Limpets - Mimicry

\section{INTRODUCTION}

Lichens are associations between an alga and a fungus (Dobson 1981, Barret 1983) which colonize diverse terrestrial and marine habitats (Ozenda \& Clauzade 1970, Dittmer 1974, Dobson 1981, Redón 1985). Living species of marine lichens are found exclusively in the intertidal area, being more abundant on rocky substrata (Ozenda \& Clauzade 1970, Henssen \& Jahns 1974, Dobson 1981, Redón 1985). The presence of lichens as epibionts, living on external surfaces of marine organisms, has been scarcely reported and the information is restricted to the Northern Hemisphere (Bonar 1936, Grant 1938, Test 1945, Giesel 1970, Ozenda \& Clauzade 1970, Lindberg 1978, Dobson 1981). For instance, along the Californian coast, Dydimella conchae Bonar inhabits shells of Acmaea Eschscholtz (= Lottiidae) species (Bonar 1936, Test 1945), barnacles, and other calcium carbonate excreting organisms (Lindberg 1978). Along British shores,
Arthopyrenia halodytes (Nyland) grows on limpet shells and barnacle plates (Dobson 1981). Ozenda \& Clauzade (1970) reported Paraphysothele halodytes (Nyland) living on barnacle plates around both European and North American coasts. These authors also reported that the cosmopolitan Thelidium litorale (Leighton) can be found both on intertidal rocks and on shells of marine invertebrates.

According to Bonar (1936), lichens assimilate calcium carbonate from the shell surfaces of the marine organisms they infect. Hence, marine intertidal lichens can be a major biological modifier of the colour and morphological external patterns of their host organisms (Grant 1938, Test 1945, Lindberg 1978).

Recent collections of barnacle and limpet species from rocky shores of Central Chile have revealed the existence of a black lichen infecting plates and shells (Espoz \& Castilla 1993). This is particularly evident for the limpet Scurria boehmita (Ramirez), but also for $S$. araucana (Orbigny) and S. ceciliana (Orbigny). In 
this paper we report on a study of this infection, and furthermore argue that the polymorphism and cryptic mimicry described by Hockey et al. (1987) for the Central Chilean limpet $S$. variabilis (Sowerby) were mistakenly interpreted, since the authors did not consider the influence of the black lichen as a modifier of limpet shell sculpturing and colour.

\section{MATERIALS AND METHODS}

Lichen identification. Two species of barnacles, Jehlius cirratus (Darwin) and Chthamalus scabrosus Darwin, and 3 species of limpets, Scurria araucana, $S$. boehmita and S. ceciliana, were surveyed for the presence of lichen. The generic taxonomic status of these limpets was reassigned from the genus Collisella Dall according to a recent study of Chilean patellogastropods (Lindberg pers. comm.). Lichen identification was based on the keys of Ozenda \& Clauzade (1970). The fruiting bodies were mounted in 'Karo', light corn syrup, which facilitated the morphological characterization of both ascocarpous and spores. Characteristics of the lichen fruiting body shape, structure and spores were used for classification (Dobson 1981).

Field sampling and measurements. In the field, prevalence of lichen was estimated in accordance with Margolis et al. (1982) as the number of individuals of a host species carrying lichen, expressed as the percentage of the total number sampled. Between March and October 1989, samples were collected along the rocky intertidal zone of Algarrobo $\left\{33^{\circ} 21^{\prime} \mathrm{S}\right.$, $\left.71^{\circ} 40^{\prime} \mathrm{W}\right)$, Central Chile. Two different habitats were sampled during low tides: (1) horizontal platforms less than $45^{\circ}$ in slope, surveyed with randomly positioned $10 \times 10 \mathrm{~cm}$ quadrats $(\mathrm{n}=20)$ and (2) small intertidal tidepools of diameters between 10 and $15 \mathrm{~cm}$ $(n=10)$. The presence of the lichen was determined by examination, with the unaided eye, of each individual's shell. To determine if lichen prevalence was similar within and between the different habitats, 2-way contingency tables were used to compare the relative prevalence frequencies in each intertidal invertebrate species.

Limpet shell structures. When analyzing limpet shell structure of Scurria araucana, S. boehmita and S. ceciliana, the descriptive terminology of MacClintock (1967) was used. Consequently, each shell layer was defined according to its position relative to the muscle attachment scar (myostracum, $m$ in Fig. 1). We considered only those shell layers lying above the myostracum, i.e. $m+1, m+2$ and $m+3$ (Fig, 1). This terminology has also been used by Cohen \& Branch (1992). Widths of the $m+1, m+2$ and $m+3$ shell layers were measured across the myostracum attachment

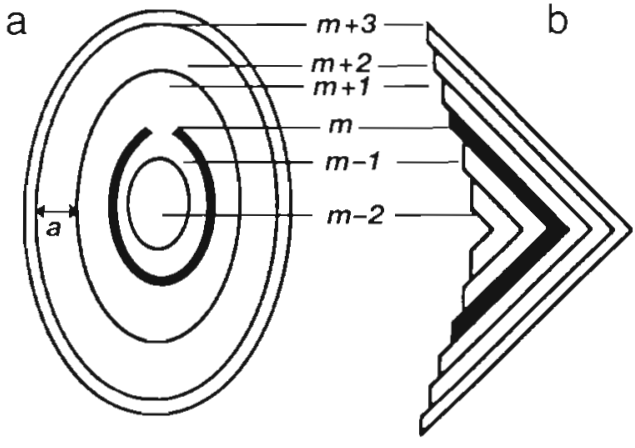

Fig. 1. Scurria spp. (a) Ventral view and (b) transverse section showing arrangement in a 5-layer structure. Arrows indicate the outer shell layer measurement points. a: each layer measured; m: myostracum. Redrawn from Cohen \& Branch (1992)

point of each shell using a dissecting microscope (Fig. 1). All measurements were taken under $40 \times$ magnification. Following Cohen \& Branch (1992), the relative width of each layer was expressed as:

Relative width $(\%)=\frac{a}{(m+1)+(m+2)+(m+3)} \times 100$

where $a$ is $(m+1),(m+2)$, or $(m+3)$ respectively (Fig. 1). In order to control for size differences between species of the 3 limpets, only shells of similar size were studied. Accordingly, the average size of the limpet shells used for measurements of layer width was $10.78 \pm 0.13 \mathrm{~mm}$ (mean length \pm standard error). Mean layer widths were compared using the GT2 method, which employs the studentized maximum modulus distribution (SMM; Sokal \& Rohlf 1981). Angular transformations were applied before analysis, which is especially recommended when the percentages cover a wide range of values (Steel \& Torrie 1980).

\section{RESULTS}

\section{Lichen identification and characterization}

Shells of limpets and barnacles were infected by a lichen with a thin, crustose and endolithic thallus. Perithecia, often immersed in the lichen thallus, were the only type of reproduction body found in the pitted limpet shells and barnacle plates. The ascospores were obovate-elliptic, smooth and contained 8 hyaline bicellular spores (Fig. 2). In accordance with Ozenda \& Clauzade (1970), these characteristics agreed with those of the lichen Thelidium litorale (Ascomycete: Verrucariaceae).

In the field, Thelidium litorale was easily recognizable due to the black fruiting bodies developed at the 


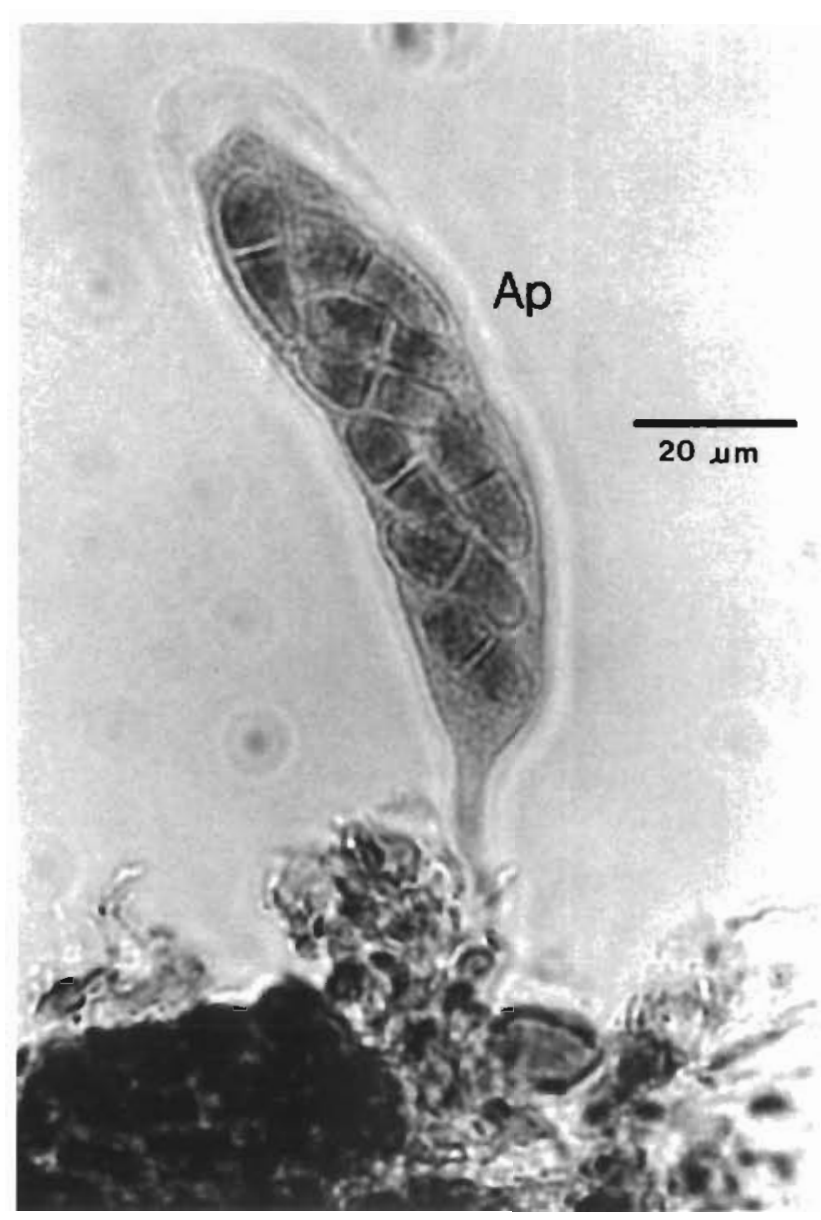

Fig. 2. Thelidium litorale. Transverse section showing the Perithecia type ascocarpous (Ap) containing 8 bicellular hyaline ascospores

shell surface of the host species. Hence, infected barnacle plates and limpet shells carried numerous black dots, many of which contained fruiting bodies (Fig. 3). Both on plates of the intertidal barnacles Jehlius cirratus and Chthamalus scabrosus (Fig. 3a, b) and on the shells of all 3 limpet species (Fig. 3c, d, e), the lichen penetrated the calcareous material without damaging the soft body tissue.

Fig. 3c, d, e shows the presence of Thelidium litorale on shells of the 3 Scurria species studied. Colonization of limpet shells by the lichen started near the apex, and often the younger marginal parts of the shell were not infected. Colonized shell areas appeared rough and greyish; the calcareous material was fragile and disintegrated easily to a granular mass. This was quite different from the hard and compact material of uninfected limpet shells (C. Espoz pers. obs.).

\section{Lichen prevalence in the field}

Estimates of Thelidium litorale prevalence in the field (Table 1) showed that lichen infection was particularly high in Scurria boehmita. In fact, $100 \%$ of the individuals collected from intertidal tidepools and $89 \%$ of the individuals found on intertidal platforms were infected by the lichen. In tidepools, $S$. ceciliana and Jehlius cirratus showed the second highest prevalence, $44.9 \%$ and $31.9 \%$ respectively, while in S. araucana, Siphonaria lessoni Blainville, Chthamalus scabrosus and the mussel Perumytilus purpuratus Lamarck infection did not exceed $11 \%$. A slightly different pattern emerged on intertidal platforms. Here J. cirratus, C. scabrosus, S. ceciliana and $P$. purpuratus had lichen prevalences of $65.7 \%, 55.6 \%, 43.0 \%$ and $32.0 \%$ respectively, whereas the prevalence in $S$. araucana and $S$. lessoni was less than $20 \%$. There was no significant difference between the lichen prevalence in tidepools and platforms $\left(\chi^{2}=513.0,6 \mathrm{df}, \mathrm{p}>0.05\right)$, the relative frequencies of lichen infection being similar in both habitats. Within each habitat, the relative frequencies of infected and non-infected species were significantly different $\left(\chi^{2}=267.5,6 \mathrm{df}, \mathrm{p}<0.001\right.$ in tidepools, and $\chi^{2}=274.4,6 \mathrm{df}, \mathrm{p}<0.001$ on platforms).

\section{Shell layer measurements}

Shell layer measurements for Scurria araucana, $S$. ceciliana and $S$. boehmita are given in Table 2 . The relative width of the $m+1$ layer in all 3 limpets was greater than half of the total shell thickness. There were significant differences between $S$. araucana and both $S$. ceciliana and $S$. boehmita $(\mathrm{SMM}=3.73,90 \mathrm{df}$, $\mathrm{p}<0.001)$. The mean width of the $m+2$ layer was similar in all species (SMM $=3.37,90 \mathrm{df}, \mathrm{p}>0.05)$. A dif-

Table 1. Thelidium litorale. Prevalence on shells of invertebrate species of the intertidal zone of Algarrobo, Central Chile. Samples were taken from tidepools and platforms. Values represent percent of individuals infected and are means (SE). N: number of individuals sampled

\begin{tabular}{|c|c|c|c|c|c|c|}
\hline Species & \multicolumn{3}{|c|}{ Tidepools } & $\%$ & $\begin{array}{l}\text { Platforms } \\
\text { Infestation }\end{array}$ & $\begin{array}{ll}\mathrm{s} & \\
\mathrm{n} & \mathrm{N}\end{array}$ \\
\hline Barnacles & & & & & & \\
\hline Jehlius cirratus & 31.9 & $9 \quad(7.5)$ & 123 & 65.7 & $(3.7)$ & 1908 \\
\hline Chthamalus scabrosus & 6.0 & $0 \quad(2.0)$ & 328 & 55.6 & $(4.2)$ & 1405 \\
\hline Gastropods & & & & & & \\
\hline Scurria araucana & 9.3 & $3 \quad(2.2)$ & 127 & 19.9 & $(4.7)$ & 73 \\
\hline Scurria boehmita & 100.0 & & 38 & 89.0 & $(3.8)$ & 168 \\
\hline Scurria ceciliana & 44.9 & $9 \quad(8.6)$ & 112 & 43.0 & $(9.3)$ & 47 \\
\hline Siphonaria lessoni & 10.5 & $5 \quad(6.3)$ & 64 & 6.2 & $(10.5)$ & 64 \\
\hline Mussels & & & & & & \\
\hline Perumytilus purpuratus & 3.3 & $3 \quad(3.4)$ & 24 & 32.0 & $(9.7)$ & 114 \\
\hline
\end{tabular}




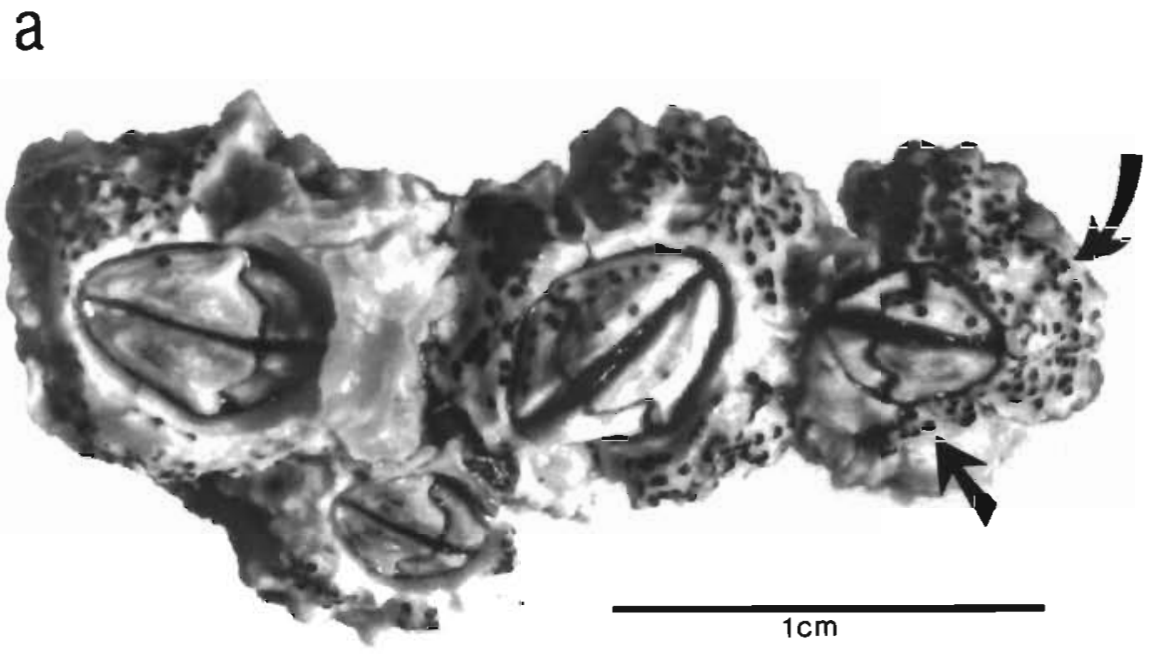

b

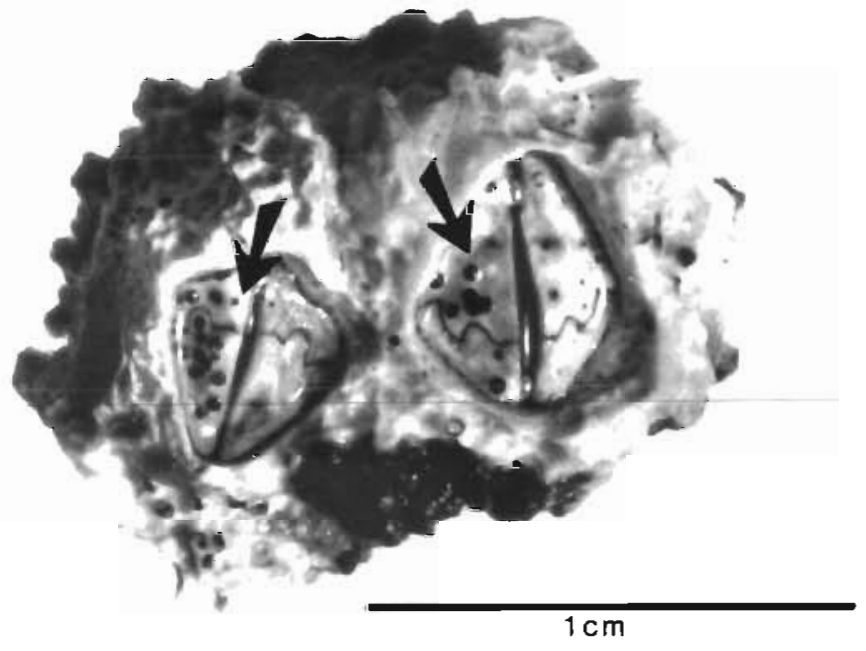

C

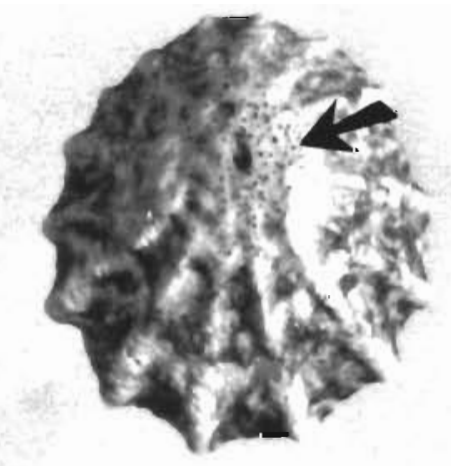

$1 \mathrm{~cm}$

e
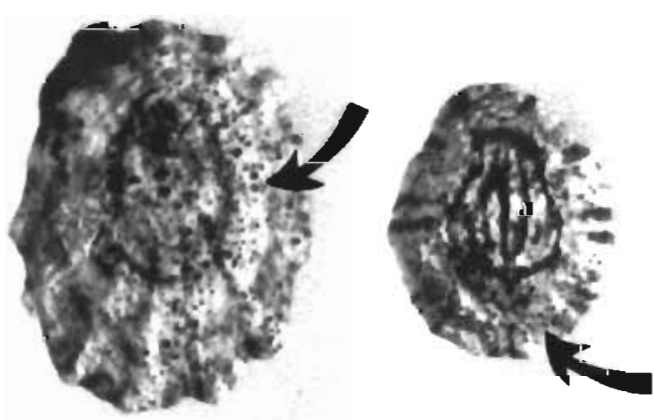

Fig. 3. Thelidium Ltorale on plates of the intertidal barnacles (a) Jehlius cirratus and (b) Chthamalus scabrosus, and on the shells of limpets (c) Scurria araucana, (d) S. ceciliana, and (e) S. boehmita. Arrows show pits where fruiting bodies develop 
Table 2. Scurria araucana, S. ceciliana and S. boehmita. Results of shell microstructure layer measurements at the collecting site. Results are given as mean percentages and SE. Ni: number of individuals sampled

\begin{tabular}{|lcccccccc|}
\hline Species & $\% m+1$ & SE & $\% m+2$ & SE & $\% m+3$ & SE & $N$ \\
\hline Scurria araucana & 65.9 & 1.2 & 19.6 & 0.8 & 14.5 & 0.6 & 32 \\
Scurria ceciliana & 74.6 & 1.2 & 19.0 & 0.9 & 6.6 & 0.3 & 27 \\
Scurria boehmita & 74.0 & 1.1 & 20.9 & 1.0 & 5.1 & 0.3 & 34 \\
\hline
\end{tabular}

and cyanophyceae algae (D. R. Lindberg pers. comm.), and $T$ litorale (Ascomycete: Verrucariacea) would represent the valid lichen name.

Thelidium itorale is the only species of the genus Thelidium inhabiting calcareous surfaces of several marine invertebrates (Dobson 1981.) and, although its distribution is cosmopolitan, there have been few studies on its association with marine organisms. On the

ferent pattern emerged regarding the mean widths of $m+3$. In this case, all the species showed significant differences among the mean widths (SMM $=2.43,90$ $\mathrm{df}, \mathrm{p}<0.05)$. S. boehmita exhibited a thinner $m+3$ layer than either $S$, araucana and $S$. ceciliana.

\section{The Scurria boehmita case}

The external shell appearance of Scurria boehmita, non-infected and infected by the lichen Thelidium litorale, and its internal appearance are shown in Fig. 4 (a, b, c respectively). In the field, shells of $S$. boehmita were subjected to high lichen infection (see Table 1). T. litorale completely changed the external shell patterns of $S$. boehmita, both in colour and morphology (compare Fig, $4 \mathrm{a}$ to $4 \mathrm{~b}$ ). The resulting colour pattern was a characteristic combination of both brown lines and black dots, although sometimes it appeared entirely brown or tan (Fig. 4b). Sometimes the darkest colour was present in the form of reticulation or concentric circles. In addition to modifying the colour, erosion of shell layers by the lichen. T. hitorale also modified the external shell sculpturing. As a result of these factors the external shell of $S$. boehmita came to remarkably resemble the appearance of the aperture of the barnacles Jehlius cirratus and Chthamalus scabrosus (compare Fig. 3a, b with 4 b), which occupy the same shore level.

\section{DISCUSSION}

Since being described by Bonar (1936), Thelidium litorale has undergone several generic and specific nomenclatural reassignments (i.e. Ozenda \& Clauzade 1970, Lindberg 1978). At present this species could be treated as a lichen, forming an association between an ascomycete rocky intertidal shores of Central Chile, $T$. litorale infects several invertebrates including valves of the mussel Perumytilus purpuratus, plates of the barnacles Jehlius cirratus and Chthamalus scabrosus, and shells of limpets (e.g. Siphonaria lessoni, Scurria araucana, S. ceciliana and $S$. boehmita) The effect of lichen infection on limpet shells was described by Bonar (1936) as
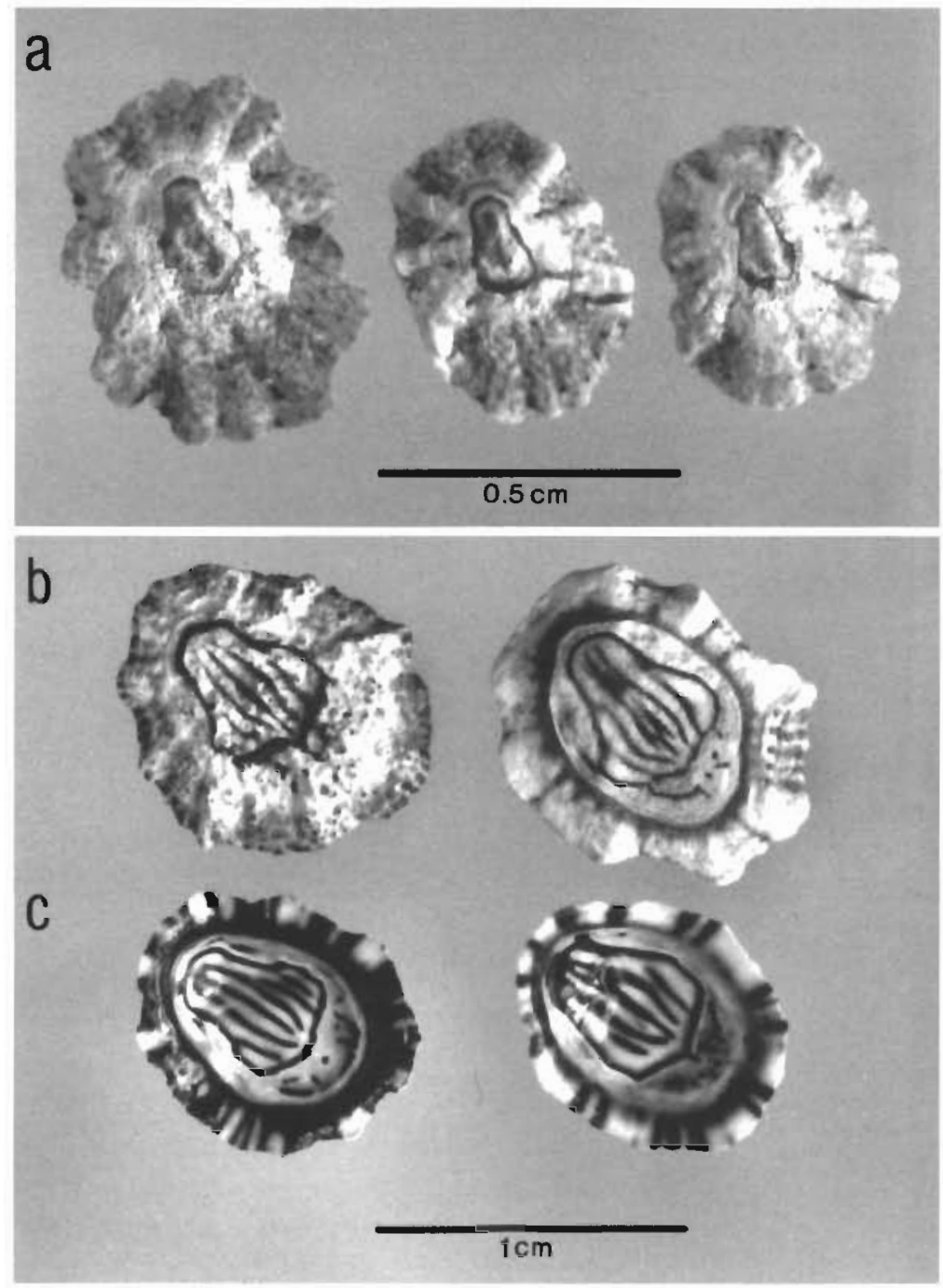

Fig. 4. Scurria boehmita. External appearance of (a) non-infected shells, (b) shells after lichen colonization, and (c) internal colour pattern 
a complete disappearance of the external shell matrix of the host $(m+2$ and $m+3$ in Fig. 1) which the lichen dissolves as a source of nutrients, using a mycelium digesting mechanism. Therefore, the depth of mycelium penetration could differ according to host species and could be related to the thickness of the shell layers. While in $S$. boehmita and $S$. ceciliana the $m+3$ layer is thin and restricted to a narrow zone, in $S$. araucana the same layer accounts for $15 \%$ of the total shell thickness (see Table 2). This could explain the lower lichen penetration level observed in $S$. araucana (Fig. 3c). On the other hand, the shell structures of $S$. boehmita and $S$. ceciliana are similar. In both species the complex-prismatic layer, $m+3$, is very thin as compared to the thick inner $m+2$ layer (see Table 2). This fact could facilitate the lichen penetration, and could explain its presence in the concentric crossed-lamellar $m+1$ layer of $S$. boehmita.

The eroding action of the lichen on the limpet shell surface completely changes the shell coloration pattern of Scurria boehmita. Frequently, this infection has resulted in taxonomic misidentification (Grant 1938, Test 1945). For instance, Hockey et al. (1987) described the occurrence of polymorphism and cryptic mimicry in a population of limpets that they identified as Scurria variabilis from the Central coast of Chile. They reported $3 S$. variabilis morphotypes and argued that selective and differential bird predation helped to maintain the polymorphism. An examination of the photographs published by the authors suggests to us that 1 of the 3 morphs (morph Type 3, the one resembling barnacles) corresponds to the species $S$. boehmita and the remaining 2 are probably either $S$. araucana or $S$. ceciliana. It is our view that Hockey et al. (1987) attributed morphotypes and argued for polymorphism on the wrong basis. In fact, as discussed earlier, Thelidium litorale penetrates the 3 shell layers of the limpet $S$. boehmita, exposing its internal shell design (Fig. 4c) and thus producing its characteristic 'barnacle-like' external pattern (Fig. 4b). Hence, the resemblance between the barnacles Jehlius cirratus and Chthamalus scabrosus and the limpet S. boehmita, interpreted by Hockey et al. (1987) as cryptic mimicry of a genotypic morph of $S$. variabilis, appears to be the outcome of the relationship between the lichen $T$. litorale and the limpet shell. In any case, the amazing lichen-mediated mimicry found in $S$. boehmita could prove advantageous to the limpet population when visual predators like birds are considered. In general, natural selection will favour the development of characteristics that make animals less conspicuous to their predators (Sørensen \& Lindberg 1991). Camouflage from predators can be achieved by either matching the inanimate physical environment (e.g. substratum colour), or mimicking another, less palatable organism.
Among intertidal limpets, cryptic colours and variable morphologies and sculptures seem to be widespread phenomena. For instance, experiments conducted by Lindberg \& Pearse (1990) in California showed that limpets of the genus Lottia can facultatively change shell colour and morphology to match the substratum they live on. In the same vein, on the coast of Vancouver Island, British Columbia, 2 species of Collisella appear to partition microhabitats according to substratum colour in order to reduce predation by fish and birds (Mercurio et al. 1985). Similarly, Giesel (1970) suggested that in the northeastern Pacific the surfbird Aphriza virgata Gmelin, which is also a common migrant along the Chilean coast (Castilla \& Paine 1987), was responsible for seasonal selection on morphs of the limpet Lottia digitalis (Rathke): limpets either lighter or darker than the microhabitat background were more conspicuous to predators. In Chile, the available evidence (see below) suggests that limpets of the genus Scurria are selectively preyed upon, and preferred over barnacles, by birds. This is particularly so for the shorebirds $A$. virgata and Arenaria interpres (Linnaeus), the oystercatcher Haematopus ater Viellot \& Ondart (Castilla 1981, C. Espoz pers. obs.), and 2 species of Cinclodes (Hockey et al. 1987). In spite of limpet species misidentification, Hockey et al. (1987) also provided evidence that Cinclodes nigrofumosus Orbingy \& Lafresnaye and C. patagonicus Gmelin preferred what they called the non-cryptic morphs of Scurria (= S. araucana and S. ceciliana) over the cryptic, barnacle-like morph (=S. boehmita).

The precise nature of the relationship between Thelidium litorale and the limpet host species studied here is a matter for further investigation. On the one hand, the lichen most likely has a parasitic (negative) effect on the limpets by eroding and weakening their shells. The consequences of the above have not been assessed, although in the extremely wave-battered environment of central Chile (Castilla 1981) it may be of biological and ecological relevance. On the other hand, the lichen appears to have a mutualistic (positive) effect on the limpets by mediating cryptic mimicry, which could increase limpet survival in the face of visual predators. The actual evolutionary significance of the lichen-limpet relationship will depend on these trade-offs and it can be expected to vary with different local predation regimes. An accurate assessment of the role of avian predation and the design of appropriate field experiments to determine these trade-offs should be the next step in research on this subject.

Acknowledgements. We thank D. Lindberg, S. Navarrete, R. Bustamante, P. Camus, B. Santelices, P. Marquet, R. Soto and $J$. Alvarado for discussion and comments on the manu- 
script, I. González, R. Alfaro, J. Alvarado, C. Pino and P. Manriquez for assistance in the field, and A. Larrea, V. Flores and J. Mancilla for photographs. We specially thank D. Lindberg for the valuable help with the shell microstructure analysis. This paper benefited greatly from criticism by R. N. Hughes, S. Hawkins and G. Branch. Finally, we acknowledge financial support from FONDECYT Research Project 3503/89 to J.C.C. and an American States Organization fellowship to C.E. The first author thanks $P$. Universidad Católica de Chile and Comisión Nacional de Investigación Científica y Tecnológica (CONICYT) for scholarships that allowed this work to be completed.

\section{LITERATURE CITED}

Barret, J. A. (1983). Plant-fungus symbioses. In: Futuyma, D. J., Slatkin, M. (eds.) Coevolution. Sinauer Associates Inc., Sunderland, MA, p. 137-160

Bonar, L. (1936). An unusual ascomycete in the shells of marine animals. Univ. Calif. Berkeley Publ. Bot. 19(5): $187-194$

Castilla, J. C. (1981). Perspectivas de investigación en estructura y dinámica de comunidades intermareales rocosas de Chile central. II. Depredadores de alto nivel trófico. Medio Ambiente 5: 190-215

Castilla, J. C., Paine, R. T (1987). Predation and community organization on Eastern Pacific, temperate zone, rocky intertidal shores. Rev. Chil. Hist. Nat. 60: 131-151

Cohen, A. L., Branch, G. M. (1992). Environmentally controlled variation in the structure and mineralogy of Patella granularis shells from coast of southern Atrica: implications for paleotemperature assessments. Palaeogeogr. Palaeoclim. Palaeoecol. 91: 49-57

Dittmer, H. J. (1974). Phylogeny and form in the plant kingdom. D. Van Nostrand Co., Inc, NJ

Dobson, F. (1981). Lichens: an illustrated guide. Richmond Publishing Co., Richmond, $\mathrm{NH}$

Espoz, C., Castilla, J. C. (1993). Características y efectos de la presencia del liquen Thelidium litorale en conchas de lapas del género Collisella. Abstract, XIII Jornadas de Ciencias del Mar, Viña del Mar, Chile, 63

Giesel, J. T. (1970). On the maintenance of a shell pattern and

This article was presented by R. N. Hughes (Senior Editorial Advisor), Bangor, UK behavior polymorphism in Acmaea digitalis, a limpet. Evolution 24: 98-119

Grant, A. R. (1938). A systematic revision of the genus Acmaea Eschscholtz, including consideration of ecology and speciation. Ph.D. thesis, Univ. of California, Berkeley

Henssen, A., Jahns, H. M. (1974). Lichenes: eine Einführung in die Flechtenkunde. G. Thieme Verlag, Stuttgart

Hockey, P. A., Bosman, A. L., Ryan, P. G. (1987). The maintenance of polymorphism and cryptic mimesis in the limpet Scurria variabilis by two species of Cinclodes (Aves: Furnariinae) in central Chile. Veliger 30(1): 5-10

Lindberg, D. R. (1978). A note on changes in marine intertidal fungus taxonomy. Veliger 20(4): 399

Lindberg, D. R., Pearse, J. S. (1990). Experimental manipulation of shell colour and morphology of limpets Lottia asmi (Middendorff) and Lottia digitalis (Rathke) (Mollusca: Patellogastropoda). J. exp. mar. Biol. Ecol. 140: $173-185$

MacClintock, C. (1967). Shell structure of patelloid and bellerophontoid gastropods (Mollusca). Peabody Mus. nat. Hist. Yale Univ. Bull. 22

Margolis, L., Esch, G. W., Holmes, J. C., Kuris, A. M., Schad, G. A. (1982). The use of ecological terms in parasitology (report of an ad hoc committee of the American Society of Parasitologist). J. Parasitol. 68(1): 131-133

Mercurio, K. S., Palmer, A. R., Lowell, R. B. (1985). Predatormediated microhabitat partitioning by two species of visually cryptic intertidal limpets. Ecology 66: 1417-1425

Ozenda, P., Clauzade, G. (1970). Les lichens: étude biologique et flore illustrée. Masson et Cie, Paris

Redón, J. (1985). Líquenes antárticos. Instituto Antártico Chileno (INACH), Chile

Sokal, R. R., Rohlf, F. J. (1981). Biometry. W. H. Freeman and Co., New York

Sorensen, F. E., Lindberg, D. R. (1991). Preferential predation by American black oystercatchers on transitional ecophenotypes of the limpet Lottia pelta (Rathke). J. exp. mar. Biol. Ecol. 154: 123-136

Steel, R. G. D., Torrie, J. H. (1980). Principles and procedures of statistics: a biometrical approach. McGraw-Hill, New York

Test, A. R. G. (1945). Ecology of Californian Acmaea. Ecology 26: $395-405$

Manuscript first received: December 2, 1993

Revised version accepted: November 29, 1994 